\title{
PENERAPAN CATUR PRAMANA SEBAGAI METODE ILMIAH DALAM PENINGKATAN MUTU PEMBELAJARAN AGAMA HINDU
}

\author{
Oleh \\ Ni Nengah Kerti \\ Sekolah Dasar Negeri 8 Subagan \\ ninengahkerti@gmail.com
}

Diterima 17 Desember 2017, direvisi 28 Januari 2018, diterbitkan 28 Pebruari 2018

\begin{abstract}
In line with the implementation of the 2013 curriculum, the term scientific approach becomes the subject of discussion that attracts the attention of educators. Applying this approach becomes a teacher challenge through the development of student activities in learning, which in Hinduism is called catur pramana. This epistemology describes four ways to acquire and develop science, which can be called the Hindu scientific method. These ways are called prataykasa pramana. anumana pramana, upamana pramana and sabda pramana. Catur pramana can be applied in the learning of Hinduism and encourage the realization of student-centered learning. The application of scientific method of catur pramana in Hindu teaching aims to improve the quality of effective and enjoyable learning.
\end{abstract}

\section{Keywords: Pramana Chess, Hindu Religion Learning}

\section{PENDAHULUAN}

Pendekatan adalah konsep dasar yang mewadahi, menginspirasi, menguatkan, dan melatari pemikiran tentang bagaimana metode pembelajaran diterapkan berdasarkan teori tertentu. Oleh karena itu banyak pandangan yang menyatakan bahwa pendekatan sama artinya dengan metode. Pendekatan ilmiah berarti konsep dasar yang menginspirasi atau melatarbelakangi perumusan metode mengajar dengan menerapkan karakteristik yang ilmiah. Pendekatan pembelajaran ilmiah (scientific teaching) merupakan bagian dari pendekatan paedagogis pada pelaksanaan pembelajaran dalam kelas yang melandasi penerapan metode ilmiah. Pengertian penerapan pendekatan ilmiah dalam pembelajaran tidak hanya fokus pada bagaimana mengembangkan kompetensi siswa dalam melakukan observasi atau eksperimen, namun bagaimana mengembangkan pengetahuan dan keterampilan berpikir sehingga dapat mendukung aktivitas kreatif dalam berinovasi atau berkarya. Menurut majalah Forum Kebijakan Ilmiah yang terbit di Amerika pada tahun 2004 sebagaimana dikutip Wikipedia 
menyatakan bahwa pembelajaran ilmiah mencakup strategi pembelajaran siswa aktif yang mengintegrasikan siswa dalam proses berpikir dan penggunaan metode yang teruji secara ilmiah sehingga dapat membedakan kemampuan siswa yang bervariasi. Penerapan metode ilmiah membantu guru mengindentifikasi perbedaan kemampuan siswa. Pada penerbitan berikutnya pada tahun 2007 dinyatakan bahwa penerapan pendekatan saintifik dalam pembelajaran harus memenuhi tiga prinsip utama; yaitu: belajar siswa aktif, dalam hal ini termasuk inquiry-based learning atau belajar berbasis penelitian, cooperative learning atau belajar berkelompok, dan belajar berpusat pada siswa. Assessment berarti pengukuran kemajuan belajar siswa yang dibandingkan dengan target pencapaian tujuan belajar. Keberagaman mengandung makna bahwa dalam pendekatan ilmiah mengembangkan pendekatan keragaman. Pendekatan ini membawa konsekuensi siswa unik, kelompok siswa unik, termasuk keunikan dari kompetensi, materi, instruktur, pendekatan dan metode mengajar, serta konteks.

Sejalan diawalinya penerapan kurikulum 2013, istilah pendekatan ilmiah, atau pendekatan saintifik, atau scientific aproach menjadi bahan pembahasan yang menarik perhatian para pendidik. Penerapan pendekatan ini menjadi tantangan guru melalui pengembangan aktivitas siswa yaitu mengamati, menanya, mencoba, mengolah, menyaji, menalar, dan mencipta. Tujuh aktivitas belajar tersebut merupakan aktivitas dalam mengembangkan keterampilan berpikir untuk mengembangkan ingin tahu siswa. Dengan itu diharapkan siswa termotivasi untuk mengamati fenomena yang terdapat di sekitarnya, mencatat atau mengidentifikasi fakta, lalu merumuskan masalah yang ingin diketahuinya dalam pernyataan menanya. Dari langkah ini diharapkan siswa mampu merumuskan masalah atau merumuskan hal yang ingin diketahuinya. Pemaparan di atas menunjukkan bahwa pendekatan ilmiah memiliki banyak kelebihan dan wajib diterjemahkan oleh guru dalam pembelajaran.

Sebuah pertanyaan menarik jika menghubungkan pendekatan ilmiah dengan agama Hindu dan pembelajaran agamanya. Dalam agama Hindu pendekatan ilmiah bukanlah hal yang baru. Mengingat dalam agama Hindu terdapat sad darsana. Dimana dalam darsana tersebut diajarkan bagaiamana memperoleh penyimpulan sebuah kebenaran. Salah satu filsafat weda yang dikenal dalam kehidupan masyarakat Hindu adalah nyaya darsana. Nyaya sesungguhnya merupakan sistem pemikiran realism logis. Dalam pemikiran realistic, eksistensi benda-benda atas objek tergantung (independen) pada pengetahuan dan pikiran pengamat (subjek). Ruang lingkup filsafat nyaya dapat dibagi menjadi empat bagian yaitu : teori pengetahuan, teori dunia fisika, teori jiwa individual dan kelepasan, serta teori tentang Tuhan (Pendit, 2007). Dalam perguruan param-param zaman upanisad dan ithiasa. Pembelajaran berlangsung dengan model-model seperti pendekatan ilmiah pada pendidikan modern. Uraian diatas menunjukkan metode ilmiah yang terdapat dalam ajaran Hindu penting untuk dipamahi sehingga dapat diterapkan oleh guru dalam pembelajaran era modern.

\section{PEMBAHASAN}

\subsection{Metode Ilmiah Hinduisme}

Epistemologi Nyaya memaparkan tentang empat cara memperoleh dan menggambarkan tentang empat cara untuk memperoleh dan mengembangkan ilmu pengetahuan, yang dapat kita sebut sebagai metode ilmiahnya Hindu. Kempat cara tersebut disebut dengan Catur Pramana (Maswinara, 1998) yaitu pengamatan (prtayaksa) Penalaran (anumana) pemodelan (upamana) dan kesaksian (sabda). Uraian terhadap keempat cara tersebut dapat dipaparkan sebagai berikut : 
a. Pratyaksa Pramana

Cara untuk memperoleh pengetahuan melalui pengamatan langsung terhadap suatu objek dengan atau tanpa menggunakan alat bantu. Berkaitan dengan Pratyaksa pramana, Filsafat nyanya mengajarkan empat faktor yang mempengaruhi kebenaran data yang diperoleh lewat pengamatan yaitu (1) keadaan subjek pengamat (2) keadaan objek yang diamati (3) keadaan hasil yang diinginkan serta (4) keadaan alat dan cara untuk mengamati Pemerolehan pengetahuan lewat pratyaksa pramana menggunakan metode induktif. Tingkat pengamatan ada dua macam yaitu : Nirvikalpa (presepsi tak pasti) dan savikalpa (perspesi pasti ) Nirvikalpa maksudnya pengamatan tanpa penilaian dan hubungan dengan subjek, sebaliknya savikalva menyangkut pengenalan secara mendalam tentang ciri-ciri dan sifat objek yang diamati. Objek pengamatan tidak hanya bersifat substansif materil tetapi juga tentang tingkah laku (praverti). Dalam proses pengamatan, alat indera pengamat memiliki hubungan khusus dengan objek sasaran (Sumawa, 1996) Hubungan antara alat indera dengan objek menimbulkan adanya persepsi. Persepsi yang muncul dari hubungan langsung antara alat indra dengan objek sasaran disebut persepsi biasa (laukika) sedangkan persepsi yang muncul dari hubungan tidak langsung, menggunakan media tertentu disebut perspsi luar biasa (alaukika). Perspsi biasa dibagai menjadi dua sesuai dengan alat panca indra yang dipakai. Penggunaan panca indera (indera luar) untuk mengamati objek tertentu berkaitan dengan unsur pembentuk dan organ alat indra tersebut. Mata hanya mampu menangkap sinar tampak untuk dapat melihat warna dan bentuk benda. Telinga hanya bisa mendengar

\section{b. Anumana Pramana}

Cara untuk memperoleh pengetahuan melalui analisis terhadap gejala-gejala yang diamati. Anumana pramana menjadi sangat penting karena tidak semua objek pengamatan bersifat kasat mata, walaupun tetap kasat logika. Pemorelahan pengetahuan dengan anumana pramana melalui lima tahapan kegiatan (silogisme) sebagai berikut:

1) Pengenalan gejala yang teramati, misalnya dari kejauahan tampak gunung mengepulkan asap

2) Pengenalan atas faktor umum penyebab gejala tersebut misalnya asap ditimbulkan oleh api.

3) Menyusun hipotesis berdasarkan gejala atau fenomena yang diamati, misalnya gunung tersebut mengeluarkan asap berarti ada api di dalamnya

4) Menerapkan aturan umum tersebut pada objek yang diamati, misalnya api tersebut berasal dari letusan yang dikeluarkannya

5) Merumuskan simpulan akhir, misalnya gunung tersebut termasuk gunung berapi. Dengan demikian pemerolehan pengetahuan lewat anumana pramana menggunakan metode deduktif

\section{c. Upamana Pramana}

Cara untuk memperoleh pengetahuan dengan membandingkan suatu objek yang akan dipelajari berdasarkan objek lain yang sudah dikenal termasuk dari persamaan dan perbedaan. Kebenaran pengetahuan yang diperoleh dengan cara seperti sangat tergantung dengan variabel yang dibandingkan. Semakin banyak variabel yang diteliti semakin besar peluang kebenarannya. Termasuk upamana pramana adalah pengetahuan yang yang diperoleh lewat analogi dan simbolik. 
Sebagai sebuah contoh seseorang belum mengenal harimau, dapat diberikan informasi bahwa harimau mirip kucing, namun jauh lebih besar. Jika suatu saat dia pergi kekebun binatang. Maka dia langsung mengenali harimau hanya dengan melihat kemeiripannya dengan kucing tersebut. lebih lanjut penggunaan simbol dan analogi sangat diperlukan dalam pembelajaran sains mengingat tidak semua objek mata pelajaran agama dapat diamati secara kasat mata

\section{d. Sabda Pramana,}

Cara untuk memperoleh pengetahuan dari kesaksian yang dapat dipercaya. Dua sumber otentik yang dimaksud adalah kesaksian dari orang yang dapat dipercaya. Dua sumber otentik yang dimaksud adalah kesaksian dari orang yang dapat dipercaya (laukika sabda dan kebenaran yang diwahyukan langsung oleh Tuhan dalam pustaka suci (waidika sabda/pemerolehan pengetahuan lewat sabda pramanasangat penting untuk memahami kebenaran akan objek yang tidak kasat mata, namun kasat logika sebagai sebuah contoh, mengakui kebenaran ungkapan yang disampaikan oleh para ilmuwan yang menyatakan bahwa garam dapur dibentuk dari reaksi unsur natrium (beracun) dengan gas klor (beracun)

Pada proses pembentukan garam dapur murni terjadi transfer electron dari atomatom logam natrium menuju molekulmolekul gas klor, sehingga terbentuk ion positif ( ation) natrium dan ion negatif (anion) klorida. Kedua jenis ion yang bermuatan berlawanan tersevut tidak bersifat racun lagi dan saling berikatan satu dengan lainnya dalam struktur isi kristal berbentuk kabus. Pandangan ilmuwan tersebut kita sebagai sebuah kebenaran. Kebenaaran itu bisa diketahui siswa dari gurunya (gurutah) atau dari dokumen sastra (sastratah) hal senada juga terjadi pada penerimaan kita terhadap penjelasan tentang tentang jiwa dalam pustaka suci. Walaupuntidak pernah melihat jiwa, namun di percaya ada sesuatu yang menyebabkan mahkluk itu, hidup dan mati jika ditinggalkannya. Akhirnya menurut filsafat Nyaya sesuatu dinyatakan benar jika sesuai denga kenyataan (korespodensi) atau dapat diterima dengan penalaran.

\subsection{Implementasi Catur Pramana Dalam Pembelajaran Agama Hindu}

Bahan kajian agama khususnya yang berkaitan dengan prilaku susila bersifat kasat mata (visible, sekalatattwa bersifat sangat abstrak, sehingga tidak kasat mata (invisible, niskala), walaupun tetap bersifat kasat logika untuk mengajarkan konsep-konsep yang bersifat abstrak, sedapat mungkin pembelajaran agama menjauhkan diri dari dogmatisme, karena dogma bisa menimbulkan efek penolakan atau sebaiknya kesetiaan sempit yang berimplikasi pada fanatisme atau bahkan radikalisme

Pembelajaran agama menghendaki adanya hubungan konseptual antara representasi teori (tattwa), tingkah laku (susila), dan simbolik (ritual). Berapa kajian empiris menunjukkan bahwa mempelajari representasi abstrak dan simbolik, seperti dewa-dewa dengan atributnya merupakan hal yang sulit dan menjemukan bagi siswa, apalagi diajarkan pada kelas rendah. Siswa cenderung hanya menghafalakan membebani pikirannya dengan sesuatu yang bersifat abstrak sehingg ilmu agama cenderung dianggap sebagai sebagai ilmu yang penuh dengan hafalan atau bahkan "dead knowledge" (Suja: 2012)

Pembuatan niyasa berupa arca dan pratima yang diperkenalkan oleh orang-orang suci di zaman purana merupakan cara yang sangat tepat jika dikaitkan dengan teori pembelajaran. Berbagai penelitian menunjukkan 
analog atau pemodelan merupakan salah satu pembelajaran konsep.

Non-observable yang banyak disarankan. Kongkritasi konsep-konsep niskala yang tidak kasat mata menggunakan model atau lambing sangat membantu siswa dalam belajar agama. Asalkan makna akan simbol-simbol tersebut diinformasikan secara jelas kepada siswa. Dalam pembelajaran agama guru tidak cukup mengajarkan apa yang mesti dipelajari siswa (what to learn) tetapi yang lebih penting bagaimana mereka belajar (how to learn) untuk itu guru harus menguasai strategi dan paedagogi untuk mengajarkan materi subjek tertentu yang oleh Shulman (1986) dalam Risdayanti dan Halim (2009) disebut sebagai pedagocy content knowledge (PCK) PCK merupakan gabungan pengetahuan isi ( content ) dan pengetahuan paedagogi untuk melakukan transformasi terhadap content supaya mudah dipahami oleh siswa yang memiliki kemampuan dan latar belakang siswa yang berbeda-beda.

Kemampuan tersebut diwujudkan dalam bentuk ilustrasi, contoh analogi, atau model. Penggunaan analogi dapat membimbing dan mengarahkan pemahaman abstrak dengan menjembatani konsep-konsep yang asing bagi pengetahuan yang telah ada pada diri siswa. Ketika siswa mampu menghubungkan konsepkonsep abstrak dengan pengalaman kesehariannya maka akan muncul dorongan instrinsik untuk mempelajari dan memahami ajarannya. Analogi juga dapat membantu siswa dalam memvisualisasi konsep-konsep abstrak dan membangun konsep-konsep agama. Konsep konsep yang abstrak dafat diformulasikan di dalam otak jika contohcontoh analogi atau model dapat ditunjukkan kepada siswa. Hal ini menegaskan bahwa analogi menyebabkan konsep-konsep yang abstrak menjadi lebih mudah diasimilasikan dengan pengetahuan siswa yang telah ada, sehingga penggunaan analogi dapat membimbing pembelajaran menjadi lebih bermakna.

Lebih lanjut, dalam kaitan dengans implementasi Catur Pramana dalam pembelajaran agama harus dipertimbangkan karakteristik dalam pembelajaran agama harus dipertimbangkan karakteristik materi yang akan diajarkan kepada siswa. Fenomena kasat mata (sekala) yang umum ada dilingkungan siswa cukup efektif dijelaskan dengan sabda pramana. Kondisi itu sangat sejalan dengan pembelajaran kontekstual (Contextual teaching and Learning).

Materi agama yang bersifat abstrak yang bersifat niskala, akan efektif jika diajarkan dan dipelajari melalui analogi dilengkapi dengan pencarian makna sebagai wujud pemerolehan pengetahuna lewat upamana dan anumanna pramana. Mengingat materi pelajaran agama bersifat holistik ada yang kasat mata tetapi banyak pula yang abstrak maka cara yang ditempuh haruslah menyesuaikan dengan karakteristik materi ajar. Kondisi siswa dan daya dukungan lingkungan sekolah. Sebagai contoh tata susila akan lebih tepat diajarkan dengan model panutan dan keteladanan dilengkapi dengan penggalian makna atas prilaku yang dilakukan sang model, baik manusia, hewan maupun alam.

Sebaliknya penjelasan tentang kemahakuasaan Tuhan yang bersifat niskala dilakukan dengan penalaran didukung dengan konsep-konsep ilmiah yang sudah diterima oleh masyarakat sebagai pengetahuan umum. Ringkasnya kegiatan belajar engajar dengan model catur pramanadapat ditunjukkan seperti tabel berikut : 


\begin{tabular}{|c|c|c|}
\hline Unsur Catur Pramana & Kegiatan Mengajar & Kegiatan belajar \\
\hline $\begin{array}{l}\text { Sabda Pramana } \\
\text { (Mencari Informasi dari } \\
\text { berbagai sumber } \\
\text { tertulis dan lisan) }\end{array}$ & $\begin{array}{l}\text { Memberitau } \\
\text { Menyuruh } \\
\text { Bertanya } \\
\text { Menyarankan } \\
\text { mendiskusikan }\end{array}$ & $\begin{array}{l}\text { Mendengarkan } \\
\text { Mengikuti } \\
\text { Membaca } \\
\text { Meringkas } \\
\text { Melaporkan } \\
\text { Mendiskusikan }\end{array}$ \\
\hline $\begin{array}{l}\text { Anumana Pramana } \\
\text { (menganalisis dan } \\
\text { menginterpretasi data) }\end{array}$ & $\begin{array}{l}\text { Bertanya } \\
\text { Membimbing } \\
\text { mendidkusikan }\end{array}$ & $\begin{array}{l}\text { Menganalisis } \\
\text { Menilai } \\
\text { Interpretasi } \\
\text { Meramalkan } \\
\text { Menyimpulkan }\end{array}$ \\
\hline $\begin{array}{l}\text { Upamana pramana } \\
\text { ( membuat analogi dan } \\
\text { model atas konsep- } \\
\text { konsep yang sedang } \\
\text { dipelajari) }\end{array}$ & $\begin{array}{l}\text { Memberitahu } \\
\text { Menyuruh } \\
\text { Membimbing } \\
\text { mendidkusikan }\end{array}$ & $\begin{array}{l}\text { Membandingkan } \\
\text { Mengklasifikasikan } \\
\text { Menganologikan } \\
\text { Memodelkan } \\
\text { Menyimpulkan }\end{array}$ \\
\hline $\begin{array}{l}\text { Pratyaksa Pramana } \\
\text { (Verifikasi dan } \\
\text { ekplorasi konsep untuk } \\
\text { perkuat pemahamanan }\end{array}$ & $\begin{array}{l}\text { Memberi contoh } \\
\text { Mendemondtrasikan } \\
\text { Bertanya } \\
\text { menyarankan }\end{array}$ & $\begin{array}{l}\text { Mengamati } \\
\text { Mendiskusikan } \\
\text { Melakukan } \\
\text { Menyimpulkan }\end{array}$ \\
\hline
\end{tabular}

\subsection{Menanamkan Widi Sradha kepada} Anak Melalui Pendekatan ilmiah

Materi pelajaran pendidikan Agama Hindu untuk Sekolah Dasar sesuai dengan peraturan Menteri pendidikan nasional nomor 22 tahun 2006 tentang standar isi untuk satuan pendidikan dasar dan menengah bertujuan (1) Menumbuh kembangkan dan meningkatkan kualitas Sradha dan Bhakti melaui pemberian, pemupukan, penghayatan dan pengamalan ajaran agama; (2) membangun insan Hindu yang dapat mewujudkan nilai-nilai Mokshatam Jagathita dalam kehidupannya.

Upaya mencapai tujuan tersebut maka ditetapkanlah standar kompetensi dan kompetensi dasar mata pelajaran Agama Hindu untuk Sekolah Dasar. Materi Widi Sradha untuk tingkat Sekolah Dasar melingkupi sifatsifat Tuhan yakni bersifat abadi (anadi ananta), tidak ada yang melahirkan (nitya), Tuhan yang menciptakan dan melahirkan diriNya sendiri (Swayambu) Tuhan ada dimanamana (wyapi-wyapaka nirwikara), mengatur alam semesta, memiliki kekuatan gaib yang susah dibayangkan (hana tan hana). Tuhan dalam ajaran agama Hindu dapat disebut dengan banyak nama sesuai dengan manifestasiNya.

Materi Widhi Srada tersebut harus diajarkan kepada anak agar memiliki keyakinan dan memahi sifat Sang Hyang Widhi. Menanamkan Widhi Sradha kepada anak dalam pembelajaran bukan perkara yang mudah. Widhi Sradha adalah sebuah konsep keyakinan yang tidak kelihatan namun menjadi sebuah keyakinan yang wajib diyakini. Walaupun secara Sabda Pramanal agamapramana kebenaraan/keyakinan akan Widhi Sradha mudah dijelaskan. Akan tetapi lebih baik siswa memperoleh keyakinan tersebut dari sebuah pengalaman belajar .

Agar siswa memperoleh pengalaman belajar maka dapat ditempuh melalui sebuah pendekatan ilmiah dalam pembelajaran. Ada beberapa pendekatan ilmiah yang dapat dilakukan guru dalam menanamkan Widhi 
Sradha kepada siswa yaitu melalui penalaran logis (anumanapramana) dan perbandingan (upamana pramana).

\subsection{Penanaman Widhi Sradha Melaui Pendekatan Ilmiah Penalaran logis (Anumana Pramana)}

Seringkali dalam proses pembelajaran agama Hindu muncul pertanyaan yang sederhana dari anak apakahSang Hyang Widhi betul ada mengingat beliau tidak dapat dilihat kasat mata ?. Menjawab pertanyaan tersebut maka guru tidak boleh semata - mata memberikan jawaban berdasarkan ayat- ayat kitab suci. Penjelasan seperti itu membuat siswa hanya sebatas tau dari membaca dan mendengarkan bukan sebuah pengetahuan yang dibangun dari pengalaman belajar. Agar anak memperoleh pengetahuan tentang pertanyaan tersebut, berikanlah jawaban yang logis dengan pendekatan ilmiah. Suruhlah anak menggambar isi lingkungan sekolah berikanlah penjelasan kertas yang awalnya bersih kemudian berisi aneka gambar karena anakanak telah membuat gambar tersebut. Kemudian ajaklah siswa keluar kelas dengan menyaksikan alam sekitar, tumbuhan, matahari, siapakah yang bisa menciptakan itu semua? tentu bukan manusia yang dapat menciptakan. Alam semesta beserta isinya merupakan ciptaan Sang Hyang Widhi. Dalam proses tersebut diawali dengan sebuah pengamatan langsung dari objek sehingga memunculkan sebuah pertanyaan pada anak. Sebelum muncul sebuah pertanyaan maka guru dapat menggiring alam pikiran siswa agar muncul sebuah pertanyaan. Darimanakah semua ini, siapakah pencipta isi alam semesta ini. Kemudian guru dapat mengksplorasi siswa dengan meminta jawaban sehinga muncul sebuah penyimpulan yang dikomunikasikan oleh siswa bahwa Sang Hyang Widhi betul - betul ada pencipta alam semesta beserta isinya.

\subsection{Menanamkan Widhi Srada melaui Pendekatan Ilmiah Perbandingan (Upamana Pramana)}

Disamping lewat penalaran logis (anumana pramana). Pendekatan ilmiah yang dapat dilakukan guru dalam menanamkan Widhi Sradhaadalah melalui perbandingan (upanama pramana). Cara perndekatan ilmiah melalui perbandingan dapat dilakukan dengan menggunakan media yang ada disekitar sekolah. Guru dapat memakai media nyata. Ada beberapa media yang dapat digunakan lewat cara perbandingan misalnya suruh tiap anak membawa gelas yang beris air kemudian larutkan air tersebut samapi butiran gula tidak terlihat. Guru dapat menyuruh anak untuk mencicipi air tersebut tentu anak tersebut akan menjawab manis, tapi ketika disuruh menemukan butiran gula tersebut tentu anak tidak dapat terlihat oleh anak. Disitulah kesempatan bagus untuk menyampaikan kepada anak tentang keberadaan Sang Hyang Widhi yang tidak terlihat namun kebesaran-Nya dapat terlihat lewat ciptaaan-Nya. Dalam pendekatan ilmiah tersebut terdapat sebuah proses pengamatan kemudian pengasosiasian sifat Sang Hyang Widhi dengan media yang digunakan sehingga ada penyimpulan yang dapat dikomunikasikan oleh siswa

Lewat pendekatan ilmiah berupa penarikan kesimpulan yang logis (anumana pramana) dan perumpamaan (upamana pramana) maka anak memiliki keyakinan akan sifat-sifat Sang Hyang Widhi sebagai pencipta alam semesta dan meresap disegala ciptaanya beserta isinya. Keberadaan Sang Hyang Widhi yang tidak terlihat tapi dapat dirasakan karena ciptaanNYa. Keyakinan tersebut diperoleh melalui pengalaman belajar secara langsung. Dengan model pendekatan ilmiah penalaran logis dan perumpamaan maka siswa memperoleh pengalaman belajar bahwa Sang Hyang Widhi betul-betul ada dan merupakan maha pencipta. 
Sehingga siswa memiliki sebuah keyakinan terhadap Sang Hyang Widhi dan memahami sifat- sifat-Nya. Keberadaan Sang Hyang Widhi memang tidak dapat diilmiahkan tapi keberadaannya dapat dijelaskan dengan pendekatan-pendekatan ilmiah kepada peserta didik.

\section{SIMPULAN}

Pendekatan ilmiah dalam Hindu bukan hal yang baru. Dalam agama Hindu terdapat tentang empat cara untuk memperoleh dan mengembangkan ilmu pengetahuan, yang disebut dengan catur pramana. Catur pramana itu terdiri dari prataykasa pramana, anumana pramana, upamana pramana,sabda pramana. Dalam pembelajaran agama Hindu metode ilmiah (catur pramana) ideal untuk diterapkan). Guru agama Hindu dapat menerapkan pembelajaran agama Hindu menggunakan metode ilmiah (catur pramana) sehingga pembelajaran agama Hindu berlangsung menarik dan dapat mencapai tujuan pembelajaran.

\section{Daftar Pustaka}

Herawan, K. D., \& Sudarsana, I. K. (2017).

Relevansi Nilai Pendidikan Karakter Dalam Geguritan Suddhamala Untuk Meningkatkan Mutu Pendidikan Di Indonesia. Jurnal Penjaminan Mutu, 3(2), 223-236.

Maswinara, I W, 1998. Tujuan Pengembaraan Kehidupan Manusia. Surabaya: Paramita
Pendit, NS 1993. Percik Pemikiran Swami Vivekananda ( terjemahan ). Jakarta : Yayasan Darma Nusantara

Sugiharta, I. P. S. O., \& Sudarsana, I. K. (2017). Hypnotic Learning Characteristics On Sisya Brahmakunta Community In Denpasar. Vidyottama Sanatana: International Journal of Hindu Science and Religious Studies, 1(2), 132-145.

Suja, I Wayan, 2012. Memahami Agama lewat Sains : Surabaya : Paramita

Risdiyani \&Lilia Halim, 2008 “ Procededing Seminar Nasional Kimia dan Ilmu Pendidikan Kimia IV" Tahun 2008 di Universitas Pendidikan Indonesia

Wisarja, I. K., \& Sudarsana, I. K. (2017). REFLEKSI KRITIS IDEOLOGI PENDIDIKAN KONSERVATISME DAN LIBRALISME MENUJU PARADIGMA BARU PENDIDIKAN. Journal of Education Research and Evaluation, 1(4), 283-291.

Wisarja, I. K., \& Sudarsana, I. K. (2017). Praksis Pendidikan Menurut Habermas (Rekonstruksi Teori Evolusi Sosial Melalui Proses Belajar Masyarakat). Indonesian Journal of Educational Research, 2(1), 18-26.

Wulandari, K., \& Sudarsana, I. K. (2017). Eksistensi Pura Ratu Gede Empu Jagat D Desa Sangkaragung Kecamatan Jembrana Kabupaten Jembrana. Jurnal Penelitian Agama Hindu, 1(2), 252-256. 